\title{
Okul öncesi öğretmenlerinin farklı eğitim yaklaşımlarını bilme durumlarının incelenmesi*
}

\author{
Examination of preschool teacher's states of knowing of different \\ educational approaches
}

\author{
Fatma Elif Kılınç ${ }^{1}$, Ferdane Karayel ${ }^{2}$, Merve Koyuncu ${ }^{3}$
}

\author{
Makalale Geçmişi \\ Geliş : : 11 Ocak 2018 \\ Düzeltme : 26 Şubat 2018 \\ Kabul : 09 Mart 2018 \\ Makale Türü \\ Özgün Makale
}

\begin{abstract}
Öz: $\mathrm{Bu}$ araştırmada resmi ve özel okullarda görev yapan okul öncesi öğretmenlerinin farklı (alternatif) eğitim yaklaşımlarını bilme durumlarının incelenmesi amaçlanmıştır. $\mathrm{Bu}$ amaç doğrultusunda Adana, Ankara ve Mersin illerinde belirlenen özel ve resmi okullardaki 42 okul öncesi öğretmeni araştırmanın çalışma grubunu oluşturmuştur. Katılımcılar amaçlı örnekleme yöntemi olan tipik durum örnekleme yöntemi ile belirlenmiştir. Araştırma nitel araştırma yöntemlerinden olgu bilim deseni ile gerçekleştirilmiştir. Araştırmada veriler yarı yapılandırılmış görüşme ile toplanmıştır. Araştırmada toplanan veriler betimsel analiz tekniği ile analiz edilmiştir. Araştırmanın bulgularına göre öğretmenlerin farklı eğitim yaklaşımlarını eğitim programına yansıtma düzeylerinin düşük, farklı eğitim yaklaşımları ile ilgili eğitimlere katılımlarının az olduğu görülmüştür. Bir diğer bulguya göre; öğretmenlerin Milli Eğitim Bakanlığı' ndan [MEB] beklentilerine yönelik verdikleri en çarpıcı sonuç hizmet içi eğitimlerin içeriğinin zenginleştirilmesi ve eğitim veren kişilerin yeterliğinin artırılması yönünde olmuştur. Bu doğrultuda öğretmenlerin hizmet öncesi ve hizmet içi eğitimlerinde farklı eğitim uygulamalarını içeren nitelikli eğitimlerin artırılmasının gerekli olduğu sonucuna varılmaktadır. Verilen hizmet içi eğitimlerin daha verimli, kapsamlı, bilgilendirici, öğretmenleri motive edici, aktif, planlı ve düzenli bir şekilde farklı ortamlarda ve farklı okullarla birlikte düzenlenmesi ve uygulanması önerilebilir.
\end{abstract}

Anahtar Kelimler: Okul öncesi eğitim, okul öncesi öğretmeni, eğitimde alternatif yaklaşımlar

Abstract: In this study aims to reveal preschool teachers' states of knowing of different educational aproaches. In this respect, 42 preschool teacher who were teaching private and public kindergarten school in Adana, Ankara and Mersin city were the study group. The participants were selected by typical case sampling method that is purposive sampling. The study was conducted using phenomenological design that is qualitative research method. For the data collection, semi-structured interview was used. The data were analyzed by descriptive analysis. According to the findings of the study, the levels of preschool teachers' reflection of different educational approaches to the training program was low and teachers do not participate in the training about different educational approaches. Teachers' expectations about Ministry of National Education was enriching the content of in service training and increasing the adequacy of trainers. Accordingly it is thought that it is necessary to increase the number of trainings which include different educational application in preservice and in-service training for teachers. It is suggested that in-service trainings be organized and implemented in a more efficient, comprehensive, informative, motivating, active, planned and regular way in different environments and with different schools.

Keywords: Early childhood education, preschool teacher, educational alternative approaches

\footnotetext{
* 5.Uluslararası Okul Öncesi Eğitim Kongresinde “sözlü bildiri” olarak sunulmuştur

${ }^{1}$ Ankara Yıldırım Beyazıt Üniversitesi, Sağlık Bilimleri Fakültesi, Çocuk Gelişimi Bölümü, fekilinc@ybu.edu.tr

${ }^{2}$ Ankara Yıldırım Beyazıt Üniversitesi, Sağlık Bilimleri Fakültesi, Çocuk Gelişimi Bölümü, ferdane.karayel@gmail.com

${ }^{3}$ Toros Üniversitesi, Meslek Yüksekokulu, Çocuk Bakımı ve Gençlik Hizmetleri Bölümü, merve.koyuncu@toros.edu.tr
} 


\section{SUMMARY}

\section{Introduction}

It is ever increasing important to handle the area of education with all elements especially with human which is main element of education. For answering "What is human being in education? What should be human in education?" returning to human beings and seeing the human in producing have revealed alternative perspective in education. Alternative education is rapidly increasing all over the world with different examples and practices based on more human, free, equal, participatory, producing and selfmanagement understanding.

From the early childhood, the question of "Is a single way appropriate for everyone in learning?" discovers understanding of education which consider individual differences. Importance of children's individual interests and needs, supporting the curiosity of children's creation and maximization of children's potentials constitute philosophical core of different educational approaches. Accordingly children need to be active and free to make decisions in the educational environment. The educator must interact with the child in the learning process as director, facilitator and helper to easy learning process. The quality of teacher and education program is very important in increasing the qualifications of education. It has important the teacher to prepare qualified educational programmes, to be informed about different approaches and models; in this approaches the roles of teacher and child, materials used, learning environment, approaches' point of view to child, to be assessed of child and to support skill of preparing individual plans. Thus, this study aims to reveal the states of preschool teachers who do in the private or public school of knowing of different educational aproaches.

\section{Method}

For this purpose, 42 preschool teacher who are teaching in private and public kindergarten school in Adana, Ankara and Mersin compose of the study group. The participants have been selected by a typical case sampling method that is purposive sampling. Half of the participating teachers (59.5\%) are over 35 years old, the vast majority (73.8\%) have bachelor's degree. $88.1 \%$ of the participants are in public school. The study have been conducted using a phenomenological design that is qualitative research method. For the data collection, semi-structured interview have been used with interview form. Interview form includes two parts. First part contains 14 questions which about personal information. Second part contains questions about which knowledge level of teachers about different educational approaches, teachers' reflection of different educational approaches to the training program, resources of teachers reading, teacher's state of participating of different educational approaches and teacher's anticipation from Ministry of National Education about different educational approaches. Individual interviews with teachers have been conducted in a quiet and calm place, involved a period of 10-15 minutes. The open-ended questions in the interview form have been asked in the same order to all the 
teachers who participated in the study. The answers of the teachers gave during the interviews were noted by the researcher. The data were analyzed by descriptive analysis

\section{Results}

According to the findings of the study, preschool teacher described alternative education as a different education than the normal education system. The levels of preschool teachers' reflection of different educational approaches to the training program was low and teachers do not participate in the training about different educational approaches. According to the another finding of the study, Montessori Approach $(n=30)$ was the most known approach by preschool teachers. This is followed by High Scope Approach ( $\mathrm{n}=12)$, Waldorf Approach $(\mathrm{n}=7)$, Reggio Emilia Approach $(\mathrm{n}=6)$, Pikler Approach $(\mathrm{n}=3)$ and Scamper Approach $(\mathrm{n}=2)$. According to the another finding of the study, teachers' anticipation from Ministry of National Education was enriching the content of in service training and increasing the adequacy of trainers.

\section{Conclusion and Discussion}

Alternative education is defined as educational models with innovative and flexible programs, which aim at providing different learning experiences to individuals and are based on individual interests and needs of students, with the exception of those used in mainstream education. From this point of view, it can be asserted that participant pre-school teachers $(n=36)$ are able to define the concept of alternative education and have a positive knowledge of alternative education.

Previous research and the conclusion of this research; when the reasons why preschool teachers did not reflect different approaches to their practice were considered, teachers may not have came across examples of applying different educational approaches, knowledge levels of teachers' about different educational approaches practice may be low and they can be lack of equipment which as educational environment, social and economic conditions and number of children.

It is thought that it is necessary to increase the number of trainings which include different educational application in pre-service and in-service training for teachers. Providing of democratic environments to children especially from the early childhood and sustainably supporting each child's own distinctive development consideringly child's learning style and speed should be the main aim of education. 


\section{GÍRIŞ}

Okul öncesi dönemde çocuğun doğasında bulunan keşfetme ve öğrenme eğilimi ile çevresini keşfettiği, iletişim kurduğu ve fikirler oluşturduğu bilinmektedir. Çocuğun içinde bulunduğu çevre, onun tüm alanlardaki gelişimi ve öğrenme motivasyonu için önemli bir unsur olarak görülmektedir. Çocuğun bu dönemde karşılaştığı deneyimler, çocuğa sunulan firsatlar ileri dönemdeki okul başarısını etkilediği gibi, öğrenmeye karşı olan tutumuna da yön vermektedir. Çocuğun gelişiminin sağlıklı olması ve öğrenmeye karşı olumlu tutumlar geliştirebilmesi için, bilişsel uyaranların nitelikli olduğu bir çevreye, çocuğa zengin dil etkileşimleri ve olumlu sosyal ve duygusal deneyimlerin sunulmasına ve çocuğun bağımsız hareket etme özgürlüğünün desteklenmesine ihtiyaç vardır. Bunun sağlanmasında nitelikli bir okul öncesi eğitimin önemi yadsınamaz bir gerçektir (MEB, 2013). Bu süreçte çocukların psiko- motor, bilişsel, sosyalduygusal gelişimlerinin, dil ve okuma- yazma becerilerinin desteklenmesi, yaratıcı yönlerinin ortaya çıkarılması ve kendilerine güvenlerinin geliştirilmesi önemlidir (Aslan, 2010; Kim ve Suen, 2003; Nacaroğlu, 2014; Siraj-Blatchford, 2004; Tominey ve Rivers, 2012; Zvoch, Reynolds ve Parker, 2008). Okul öncesi eğitim, çocukların yaratıcılıklarını ve hayal güçlerini geliştiren, onların ilgi ve ihtiyaçlarını karşılayan, çocuklara gözlem yapma, araştırmainceleme, düşüncelerini ifade etme ve problem çözme becerisi kazandıran nitelikte olmalıdır. Çocukların paylaşabilen, işbirliği yapan, başkalarının duygularını anlayan, sorumluluk alabilen bireyler olarak yetişmelerini sağlamalı, olumlu bir benlik duygusu geliştirmeleri, kendilerini ifade edebilmeleri ve güven duygusu kazanabilmelerine yardımcı olmalıdır (Yazar, 2007). Kaliteli bir okul öncesi eğitim kaliteli bir eğitim programını da gerektirmektedir. Geliştirilen eğitim programı çocuğun tüm yönlerinin gelişimi, bireysel ihtiyaçları, çocuğun ailesiyle etkileşimi, öğrenme ortamları, etkili öğrenme gibi önemli noktaların belirlenmesinde büyük rol oynamaktadır (Temel, 2012). Ülkemizde okul öncesi eğitime devam eden çocuklarına zengin öğrenme yaşantıları sağlayarak; onların psiko- motor, sosyal- duygusal, dil ve bilişsel gelişimlerini desteklemek, öz bakım becerilerini artırmak ve çocukları ilkokula hazırlamak amacıyla eğitim programı geliştirilirken; çeşitli ülkelerdeki farklı yaklaşım ve modellerini temel alan okul öncesi eğitim programları incelenmiş; farklı öğrenme kuram ve modellerinde yer alan çocuk merkezli uygulamalardan yararlanılarak eklektik bir program oluşturulmuştur (MEB, 2013).

Tüm eğitim yaklaşımları ve modellerinin temel felsefesinde çocukların bireysel ilgi ve ihtiyaçlarının önemsenmesi, doğalarındaki merak duygusunun desteklenmesi ve potansiyellerinin en üst düzeye çıkarılması yatmaktadır (Şahin, 2014). Bu yüzden çocukların 
eğitim ortamında aktif, karar verme özgürlüğüne sahip olması gerekmektedir. Öğretmen ise çağdaş bir program anlayışını benimseyerek çocukları teşvik etmeli, çocukların öğrenmelerini kolaylaştırmalı, öğrenme sürecinde çocukla etkileşim halinde olmalıdır (Temel, 2005). Okul öncesi öğretmenlerinin lisans eğitimleri süresince nitelikli eğitim programları hazırlayabilecek yeterliğe sahip olmaları, farklı yaklaşım ve modellerle ilgili bilgilendirilmeleri önemlidir. $\mathrm{Bu}$ farklı yaklaşımlarda öğretmenin ve çocuğun rolü, kullanılabilecek materyaller, öğrenme ortamı, yaklaşımın çocuğa bakış açısı, çocuğun değerlendirilmesi, aylık ve günlük plan hazırlama konusunda öğretmenlerin düşünce geliştirmelerinin desteklenmesi önemlidir (Soydan, 2013). Ele alınan farklı yaklaşım ve modeller arasında Montessori Yaklaşımı, Reggio Emilia Yaklaşımı, Proje Yaklaşımı, High Scope Yaklaşımı, Head Start Yaklaşımı, Bank Street Yaklaşımı, Yapılandırmacı Yaklaşım, Waldorf Yaklaşımı, Açık Eğitim, Çocuktan Çocuğa Yaklaşım, Ev okulu yer almaktadır (Şahin, 2014; Temel, 2012; Başal, 2010).

Yükseköğretim Kurulu Eğitim Fakültesi Öğretmen Yetiştirme Lisans Programı'na göre (YÖK, 2007) Okul Öncesi Öğretmenliği Lisans Programı’nda farklı yaklaşım ve modeller ile ilgili zorunlu bir ders yer almamaktadır. Üniversitelerde “Özel Öğretim Yöntemleri I- II" dersi kapsamında farklı yaklaşım ve modeller ele alınmaktadır. Bunun dışında bazı üniversitelerin müfredatında özel olarak seçmeli dersler bulunmaktadır. Türkiye'deki üniversitelerin web adreslerinde yer alan içeriklere göre farklı yaklaşımlarla ilgili ulaşılan dersler Tablo 1 de gösterilmiştir.

Tablo 1. Üniversitelerde eğitim fakültesi okul öncesi ögretmenliği lisans programında yer alan dersler

Hacettepe Üniversitesi
Okul Öncesi Öğretmenliği Lisans Programı
Bülent Ecevit Üniversitesi
Okul Öncesi Öğretmenliği Lisans Programı
Çukurova Üniversitesi
Okul Öncesi Öğretmenliği Lisans Programı
Erzincan Üniversitesi
Okul Öncesi Öğretmenliği Lisans Programı
Muğla Sitkı Koçman Üniversitesi
Okul Öncesi Öğretmenliği Lisans Programı
Pamukkale Üniversitesi
Okul Öncesi Eğitimi Lisans Programı
Sinop Üniversitesi
Okul Öncesi Eğitimi Lisans Programı
Yıldı Teknik Üniversitesi
Okul Öncesi Eğitimi Lisans Programı

\begin{tabular}{|c|}
\hline "Karşılaştırmalı Erken Çocukluk Eğitimi" \\
\hline “Okul Öncesi Eğitimde Çağdaş Yaklaşımlar” \\
\hline "Proje Yaklaşımı ve Uygulamaları" \\
\hline "Okul Öncesi Eğitimde Farklı Yaklaşımlar" \\
\hline "Okul Öncesi Eğitimde Çağdaş Yaklaşımlar" \\
\hline “Okulöncesi Eğitim Modelleri” \\
\hline "Okul Öncesi Eğitimde Program" \\
\hline $\begin{array}{l}\text { “Okul Öncesi Eğitimde Çağdaş Yaklaşımlar” } \\
\text { "Okul Öncesi Dönemde Farklı Yaklaşımlar” }\end{array}$ \\
\hline
\end{tabular}

Tablo 1' de gösterilen dersler "seçmeli ders" olarak programda yer almaktadır. Derslerin amacı genel olarak, öğrencilerin Türkiye’ de ve dünyada kabul gören, okul öncesi eğitimin temelini oluşturan kuramları, yaklaşımları, modelleri tanımaları, incelemeleri, karşılaştırmalar yapabilmeleridir. Eğitim Fakültesi Okul Öncesi Öğretmenliği lisans programlarında yer alan 
seçmeli ders içerikleri Fakültelerin web sayfalarından incelendiğinde; dersler ülkemizde ve yurt dışında kullanılan çeşitli erken çocukluk eğitim programlarının incelenmesi, programın ilke ve standartları, Montessori Yaklaşımı, High Scope Programı, Proje Yaklaşımı, Head Start Programı, Reggio Emillia Yaklaşımı, Bank Street Yaklaşımı, Waldorf Yaklaşımı, Yaratıcı Oyun Yaklaşımı, Whariki Programı, İlk Yıllar Programı, Aggazi Okulları gibi modellerin karşılaştırılması ve genel değerlendirme gibi konuları kapsamaktadır.

Yapılan literatür taraması sonucunda okul öncesi öğretmenlerin eğitim planlarını hazırlarken temel alabilecekleri yaklaşım ve modeller ile ilgili düşüncelerini, bilgi düzeylerini belirleyen çalışmaların yetersiz olduğu görülmektedir (Memduhoğlu, Mazlum ve Alav, 2015; Kalıpçı, 2008). Yapılan bu araştırma, okul öncesi eğitimde farklı yaklaşımlar ile ilgili okul öncesi öğretmenlerinin görüşlerine yer verilmesi, okul öncesi öğretmenlerinin bu konudaki yeterliliklerinin ortaya çıkarılması ve konu ile ilgili araştırmalar yapılmasının teşvik edilmesi konusunda önem taşımaktadır. Bu doğrultuda araştırmayla resmi okullar ve özel okullarda görev yapan okul öncesi öğretmenlerinin farklı (alternatif) eğitim yaklaşımlarını bilme durumlarının incelenmesi amaçlanmıştır.

\section{YÖNTEM}

\section{Araştırmanın Deseni}

Araştırma okul öncesi öğretmenlerinin “farklı eğitim yaklaşımları" ile ilgili görüşlerini ortaya koymak amacıyla nitel araştırma yöntemlerinden olgu bilim deseni kullanılarak gerçekleştirilmiştir. Olgu bilim deseninde amaç, belirli bir durumu aydınlatmak, kişilerin çevrelerindeki olaylar ve olgularla ilgili deneyimleri, kavramsallaştırmaları, algıları ve anlayışlarındaki niteliksel farklılıkları ortaya çıkarmaktır. Olgu bilim çalışmalarında görüşmeler, katılımcı gözlem, odak grup görüşmeleri, kişisel metin analizleri gibi birçok yöntem kullanılmaktadır (Lester, 1999; Marton, 2001). Bu araştırmayla okul öncesi öğretmenlerinin "farklı eğitim yaklaşımları" ile ilgili görüşleri, algıları ve bilgi düzeylerine odaklanılmıştır.

\section{Çalışma Grubu}

$\mathrm{Bu}$ araştırmada okul öncesi öğretmenlerinin alternatif eğitim yaklaşımlarını bilme durumları incelenmiştir. Katılımcı öğretmenler amaçsal örnekleme yöntemlerinden tipik durum örnekleme yöntemine göre seçilmiştir. Tipik durum örnekleme, fazla sayıdaki durumdan olağandışı olmayan, tipik bir durumun belirlendiği örnekleme yöntemidir (Büyüköztürk, Çakmak, Akgün, Karadeniz ve Demirel, 2014). Katılımcılar Ekim- Aralık 2016 tarihleri 
arasında Adana, Ankara ve Mersin illerinde belirlenen özel ve resmi anaokullarında görev yapan 41'i kadın, 1' i erkek toplam 42 okul öncesi öğretmeninden oluşmaktadır. Katılımcı öğretmenlerin yarısından fazlası $(\% 59,5) 35$ yaş ve üzeri, büyük çoğunluğu $(\% 73,8)$ lisans mezunudur. Katılımcıların \%88,1' i resmi okulda görev yapmaktadır.

\section{Veri Toplama Araçları}

Çalışmada okul öncesi öğretmenlerinin farklı eğitim yaklaşımlarıyla ilgili görüşleri, algıları ve bilgi düzeylerini belirlemek amacıyla "Farklı Eğitim Yaklaşımları Bilgi Düzeyi Görüşme Formu" kullanılmıştır.

“Farklı Eğitim Yaklaşımları Bilgi Düzeyi Görüşme Formu”: Okul öncesi öğretmenlerinin farklı eğitim yaklaşımları hakkındaki görüşlerini bildirdikleri yarı yapılandırılmış açık uçlu görüşme formudur. Yarı yapılandırılmış görüşmeler katılımcıların hem sabit seçenekleri olan soruları cevaplamalarını sağlayan hem de araştırmacının alanda derinlemesine ilerleyebilmesine olanak tanıyan soruları içeren görüşmelerdir (Büyüköztürk vd., 2014). Form iki bölümden oluşmaktadır. Birinci bölüm; öğretmenlerin kişisel bilgilerini belirttikleri 14 sorudan oluşmaktadır. İkinci bölüm; öğretmenlerin hangi farklı eğitim yaklaşımlarını bildikleri, eğitim programlarına nasıl yansıttıkları, farklı eğitim yaklaşımları ile ilgili okudukları kaynakların neler olduğu, bu konuyla ilgili eğitimlere katılıp katılmadıkları ve farklı eğitim yaklaşımları ile ilgili Milli Eğitim Bakanlığı’ ndan neler bekledikleri gibi soruları içermektedir.

Görüşme formu hazırlanmadan önce alanla ilgili literatür taranmıştır. Konuyla ilgili taslak sorular oluşturulduktan sonra görüşme formu bir çocuk gelişimi ve eğitimi uzmanı bir de okul öncesi okul öncesi eğitimi uzmanı olmak üzere iki alan uzmanı öğretim üyesinin görüşüne sunulmuştur. Uzman görüşleri doğrultusunda iki soru anlam bakımından değiştirilerek soru formuna son hali verilmiştir. Yapılan düzenlemeler sonucunda hazırlanan form iki okul öncesi öğretmenine ön uygulama kapsamında sorularak, öğretmenler tarafindan anlaşılmayan sorulardan üç tanesi daha açık ve anlaşılır hale getirilerek görüşme formu araştırmada kullanılmak üzere hazır duruma getirilmiştir.

\section{Verilerin Toplanması}

Araştırmada çalışma grubu belirlendikten sonra okullar ziyaret edilmiş ve seçilen okulların müdür/ müdür yardımcılarına çalışma hakkında bilgi verilerek izin alınmıştır. İdarenin bilgilendirilmesinin ardından görüşme yapılacak okul öncesi öğretmeni ile tanışılarak, çalışma hakkında bilgi verilmiştir. Öğretmenlerle gerçekleştirilen bireysel görüşmeler 10-15 dakikalık bir süreyi kapsamış ve sakin bir mekânda gerçekleştirilmeye çalışılmıştır. "Farklı Eğitim

$$
\begin{aligned}
& \text { Erken Çocukluk Çalışmaları Dergisi } \\
& \text { Cilt } 2 \cdot \text { Say1 } 2 \cdot \text { May1s }
\end{aligned}
$$

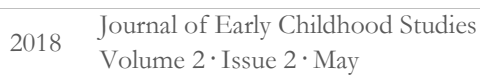


Yaklaşımları Bilgi Düzeyi Görüşme Formu” nda yer alan açık uçlu sorular araştırmaya katılan tüm öğretmenlere aynı sırayla sorulmuştur. Öğretmenlerin görüşmeler esnasında verdikleri cevaplar, araştırmacı tarafından not alınarak kaydedilmiştir. Yapılan görüşmeler sonrasında öğretmenlere katılımlarından dolayı teşekkür edilmiştir.

\section{Verilerin Analizi}

Okul öncesi öğretmenleriyle yapılan görüşmelerden elde edilen veriler betimsel analiz tekniği kullanılarak yorumlanmıştır. Betimsel analiz tekniği ile araştırmada toplanan veriler önceden belirlenmiş olan başlıklar veya temalara göre sınıflandırılmakta, özetlenmekte ve yorumlanmaktadır (Yıldırım ve Şimşek, 2003).

\section{BULGULAR}

$\mathrm{Bu}$ bölümde okul öncesi öğretmenlerinin alternatif eğitim yaklaşımlarını bilme durumlarının incelenmesi amacıyla hazırlanan Farklı Eğitim Yaklaşımları Bilgi Düzeyi Görüşme Formundan elde edilen bulguların analizi sunulmaktadır.

Farklı Eğitim Yaklaşımları Bilgi Düzeyi Görüşme Formunda yer alan ve birinci soru olan “Alternatif Eğitim denildiğinde aklınıza gelen nedir?” sorusuna yönelik 36 öğretmen görüş bildirmiştir. Katılımcı öğretmenlerin verdikleri cevaplara göre, öğretmenler alternatif eğitimi normal eğitimden farklı olarak uygulanan eğitim olarak tanımlamaktadırlar.

"Normal eğitimin dışında farklı yöntemlerin kullanıldığ1 eğitim türü.” (Ö2), "Programda olmayan ama gerekli olan ve güncel olan.” (Ö3), "Geleneksel olmayan farklı yaklaşımlarla verilen eğitim.” (Ö5), “Günlük programın dışında yapılan eğitim.” (Ö9), “Okul dışındaki eğitim, müfredat dışı eğitim, doğada eğitim." (Ö18), "Normal eğitimin dışındaki farklı yaklaşımlar" (Ö21), "Süregelenin dışında farklı yaklaşım ve teknikle eğitim.” (Ö26), "Eğitimde farkl1 yöntem ve teknolojilerin kullanılması diğer ülkelerden örneklere yer verilmesi." (Ö37), "Normal eğitim sisteminden farklı uygulanan eğitim.”(Ö40), "Eğitimde uygulanan metodun dışında bir eğitim." (Ö41).

Katılımcı öğretmenlerin Farklı Eğitim Yaklaşımları Bilgi Düzeyi Görüşme Formunda yer alan "Alternatif Eğitim, okulsuz eğitim, ebeveyn insiyatifli okul gibi girişimler ile ilgili bir bilgiye sahip misiniz, neler biliyorsunuz?” sorusuna verdikleri cevaplara göre, öğretmenlerin yaklaşık yarısı ( $\mathrm{n}=20)$ bu konuda fikir sahibi olmadığı yönünde görüş bildirmiştir. Öğretmenlerin 15 tanesi bu girişimleri sadece duymuş olduklarını fakat konu hakkında çok fazla bilgiye sahip olmadıklarını belirtmişlerdir. Katılımcı öğretmenlerden yedi tanesi ise; 
"Evet, okulsuz eğitim duydum yurtdışında. Bizde de birkaç örneği olduğunu duydum.” (Ö9), "Evet, alternatif eğitim kitabında okumuştum." (Ö11), "Evet, okulsuz eğitim örneklerini görüyorum. Evde eğitimin daha iyi olabileceğini düşündükleri için evde eğitimi savunuyorlar." (Ö13), "Evet, evde eğitim veren aileler var ama faydalı değil." (Ö14), "Evet, Amerika'da yapıldığını duydum.” (Ö16), "Evet, ebeveyn insiyatifli okulu Montessori’yi araştırırken aile katılımı olduğu için görmüştüm.” (Ö36), "Ebeveyn insiyatifli okul, velilerin eğitime daha çok katılması (veli kat1lımı).” (Ö37)

gibi ifadeler kullanarak bu girişimler ile ilgili neler bildiklerini, fikirlerini ve nerelerde karşılaştıklarını belirtmiştir.

Katılımcı öğretmenlerin Farklı Eğitim Yaklaşımları Bilgi Düzeyi Görüşme Formunda yer alan “Okul öncesi eğitimde uygulanan farklı yaklaşımlardan hangilerini biliyorsunuz?" sorusuna verdikleri cevaplara göre, öğretmenler tarafından en çok bilinen yaklaşımın Montessori Yaklaşımı (n=30) olduğu görülmüştür. Bunu High Scope Yaklaşımı (n=12), Waldorf Yaklaşımı $(\mathrm{n}=7)$, Reggio Emilia Yaklaşımı $(\mathrm{n}=6)$, Pikler Pedagojisi $(\mathrm{n}=3)$ ve Scamper Yaklaşımı $(\mathrm{n}=2)$ takip etmektedir.

Katılımcı öğretmenlerin Farklı Eğitim Yaklaşımları Bilgi Düzeyi Görüşme Formunda yer alan "Eğitim programına yansıttığınız yaklaşım var mı? Nasıl uyguluyorsunuz, neler yapıyorsunuz?" sorusuna verdikleri cevaplara göre, katılımcı öğretmenlerin çok az bir kısmı (n=6) bu konuda düşüncelerini belirtmişlerdir. Öğretmenler;

"Montessori, okulumuzda bulunan yaşam merkezlerinde uyguluyoruz. Çocuklara kendi sorumluluklarını vererek gün içinde kendi ihtiyaçlarını kendilerinin karşılama sorumluluğunu veriyoruz.” (Ö4), "Gerçek Montessori eşyaları getirerek uyguluyorum. Eğitici materyaller almaya çalışıyorum.” (Ö17), "Hepsini harmanlayıp çocuklara indirgemeye çalışıyorum. Eğitim anlayışı ve felsefesini benimsemeye çalışıyorum." (Ö20), "Scamper yaklaşımı, çeşitli sorularla çocuğun öğrenmesini sağlayan etkinlikler." (Ö24), "Daha çok Montessori, çocukların eğitim ortamını, materyalleri birlikte hazırlamayı, yaparak- yaşayarak öğrenmeyi amaçlıyoruz. Gün içinde etkinlikleri birlikte hazırlıyoruz. Waldorf' da nasıl sorularının cevaplarını arıyoruz.” (Ö25), “Materyallerimiz yok, velilerden istiyoruz. Montessori yaklaşımı’ ndan kapak- bardak kullanarak taşıma- transfer etkinlikleri yapıyoruz." (Ö36) şeklinde ifadeler kullanmışlardır.

Buradan öğretmenlerin birebir herhangi bir farklı eğitim yaklaşımını günlük eğitim akışlarına ve eğitim programlarına açıkça yansıttıkları söylenemez.

Katılımcı öğretmenlerin Farklı Eğitim Yaklaşımları Bilgi Düzeyi Görüşme Formunda yer alan “Farklı yaklaşımlara ilişkin okuduğunuz kitap, makale vs. var mı? Varsa nelerdir?” sorusuna 
verdikleri cevaplara göre, öğretmenlerin çok büyük bir kısmının $(n=38)$ farklı eğitim yaklaşımlarıyla ilgili herhangi bir kitap veya makale okumadığı görülmüştür. Bu konuda görüş bildiren 4 öğretmen ise "Montessori kendi kitabı." (Ö2), "Eğitimde farkl yaklaşımlar kitabı." (Ö11), “Eğitime bakış dergisinde Reggio Emilia.” (Ö15), “Yüksek lisans doktora tezlerini okuyorum.” (Ö36) şeklinde ifadeler kullanmışlardır. Buradan okul öncesi öğretmenlerinin farklı eğitim yaklaşımları konusunda basılı ve yazılı materyal okuma konusundaki girişimlerinin az olduğu ve özel olarak farklı yaklaşımlara dair kitap, makale, dergi okuma düzeylerinin düşük olduğu söylenebilir.

Farklı Eğitim Yaklaşımları Bilgi Düzeyi Görüşme Formunda yer alan "Farklı yaklaşımlara ilişkin takip ettiğiniz web sayfası, sosyal medya kullanıcısı, blog vs. var mı? Varsa nelerdir?" sorusuna göre öğretmenlerin yaklaşık yarısı $(n=19)$ herhangi bir web sayfası, sosyal medya kullanıcısı, blog takip etmediğini belirtmiştir. Bu konuda görüş bildiren 23 öğretmen ise internette, sosyal medyada çeşitli sayfaları takip ettiğini belirtmiştir. Fakat öğretmenlerin belirttikleri internet adresleri veya sosyal medya kullanıcıları farklı yaklaşımlara ilişkin spesifik sayfalar olmayarak, farklı yaklaşımlarla ilgili özel bilgiler ve paylaşımlar yapmamaktadır.

“Pinteres.”(Ö7), “Eğitimpedia, Pinteres.” (Ö16), “Akademisyenanne, İçimizdeki Çocuk, Mustafa Uslu.” (Ö25), "İnstagram, Montessori metodları, yabancı kaynaklı siteler okul öncesi ile ilgili eğitici oyuncaklar öğretmen siteleri.” (Ö30), “Oyuncu anne, önce okul öncesi, Buket Çokyiğit.” (Ö32), “Okul öncesi farklı çocuk, internetten okul öncesi sayfaları.” (Ö37).

Farklı Eğitim Yaklaşımları Bilgi Düzeyi Görüşme Formunda yer alan “Okul öncesi eğitimde farklı yaklaşımlarla ilgili eğitimlere katıldınız mı?” sorusuna göre öğretmenlerin büyük çoğunluğu $(n=31)$ bu tarz eğitimlere katılmadığını belirtmiştir. Herhangi bir eğitime katılmadığını belirten 31 öğretmenden $26 s ı$ ise farklı eğitim yaklaşımlarıyla ilgili eğitimler düzenlenmesi durumunda katılmayı düşündüklerini dile getirmişlerdir. Öğretmenlerin katıldıkları eğitimlerin hangi kurum ve kuruluşlar tarafindan verildiği incelendiğinde ise öğretmenlerin ifadeleri aşağıdaki gibi olmuştur:

“Ankara Üniversitesi, Küçük Eller Okulları, 2-4 gün.” (Ö3), “Montessori Eğitimi MEB Hizmet İçi Eğitim, 5 gün.” (Ö15), “Oran Küçük Şeyler Akademisi, 7 gün.” (Ö16), "Muradiye Eğitim Kurumları, Türk Telekom Kreşi, 8 aylık (her ay 2 saat).” (Ö24), “Selçuk EDU, 2 gün.” (Ö25).

Farklı Eğitim Yaklaşımları Bilgi Düzeyi Görüşme Formunda yer alan "Bu tür eğitim ve bilgilendirmelere sahip olma hususunda Milli Eğitim Bakanlığı' ndan beklentileriniz nelerdir?” sorusuna göre öğretmenler genel olarak Milli Eğitim Bakanlığı tarafindan verilen hizmet içi eğitimlerinin içeriği, eğitimciler ve bilgilendirme konularında talepte bulunduklarına ilişkin 
yanıtlar vermişlerdir. Öğretmenler verilen eğitimlerin daha verimli, kapsamlı, bilgilendirici, öğretmenleri motive edici, aktif, planlı ve düzenli bir şekilde farklı ortamlarda ve farklı okullarla birlikte düzenlenmesi ve uygulanması gerektiğini düşünmektedir. Ayrıca eğitimi veren kişilerin yeterliliklerinin artırılması ve eğitimlerin uygun şekilde öğretmenlere duyurulması ve öğretmenlerin bilgilendirilmesi gerektiğini de belirtmişlerdir.

"Eğitimlerden daha fazla haberdar olmayı ve eğitimi verecek hocaların deneyimli olmasını beklerim.” (Ö3), "Daha iyi ve çok eğitim verilmeli. Bu sürece veli, öğretmen katılarak kapsamlaştırılması olabilir." (Ö12), "Biz eğitimcilerin bu tür eğitimlerden haberdar olması ve kendini geliştirmesi için düzenli olarak bu aktivitelerden geçmesi gerekir diye düşünüyorum.” (Ö24), "Ulaşabileceğimiz şekilde duyuruların yapılması ve bu eğitimlerin planlı bir şekilde sık sık yapılması." (Ö25), "Düzenlenen hizmet içi eğitimlerin yeterli olduğunu düşünmediğim için katılmıyorum. Daha bilgilendirici ve yeterli sürede verilen eğitimler olursa katılmayı düşünürüm.”(Ö27), “Seminerlerin güncel konularla ilgili düzenlenmesi, diğer ülkelerle bağlantı olması. Farklı özel okullarla birlikte seminer almamız, farklı- yaklaşım farklı bakış açıları önemli.” (Ö36), "Eylül ve Haziran dönemi kendi okullarımızda veya başka okullarda 1 hafta veya 2 haftalı uzmanlarca verilen seminerleri düzenlenmesini isterim.” (Ö37), "Şahsen bildirilmesi, mesaj yollayabilirler. S1k duyurabilirler.” (Ö40)

Bulguları özetlemek gerekirse, kısaca okul öncesi öğretmenlerinin alternatif eğitim ve eğitimde farklı yaklaşım ve modeller ile ilgili teorik olarak bilgi sahibi oldukları fakat sınıf içi uygulamalarına bu bilgilerini yansıtmadıkları söylenebilir. Elde edilen bulgular ışı̆̆ında sonuç ve tartışma bölümü aşağıda sunulmuştur.

\section{SONUÇ VE TARTIŞMA}

Okul öncesi öğretmenlerinin farklı eğitim yaklaşımlarını bilme durumlarının incelenmesinin amaçlandığı araştırmanın bulguları çerçevesinde, katılımcı öğretmenler alternatif eğitimi ağırlıklı olarak "Normal eğitimin dışında farklı yöntemlerin kullanıldığı eğitim türü." (Ö2), "Normal eğitimin dışındaki farklı yaklaşımlar" (Ö21), "Eğitimde uygulanan metodun dışında bir eğitim.” (Ö41) gibi ifadelerle "normal eğitim sisteminden farklı uygulanan eğitim” olarak tanımlamışlardır. Alternatif eğitim en basit anlamıyla ana eğitimde kullanılanın dışında, bireylere farklı öğrenme yaşantıları sağlamayı amaçlayan, öğrencilerin bireysel ilgi ve ihtiyaçlarının fazlasıyla temele alındığı, yenilikçi ve esnek programlara sahip eğitim modelleri olarak tanımlanmaktadır (Kaya ve Gündüz, 2015). Alternatif eğitim yaygın eğitimsel düşünce yapısına karşı, farklı yaşantılar sunmakla ilgilidir. Öğrencilerin bireysel ihtiyaçlarına odaklanmasının yanında bütün insanları geliştirmeyi amaçlaması ve çevresel faktörler 
tarafından desteklenmesinden ötürü bütüncül bir özelliğe sahiptir (Carnie, 2003). Buradan katılımcı okul öncesi öğretmenlerinin $(n=36)$ alternatif eğitim kavramını tanımlayabildikleri, alternatif eğitime dair olumlu bir yönde bilgi sahibi oldukları söylenebilir. Herhangi bir fikri olmadığını ifade eden öğretmenlerin hizmet öncesinde bu yaklaşımlara ilişkin eğitim almadıkları ve farklı yaklaşımlara ilişkin merak ve ilgilerinin olmadığı düşünülmektedir. Öğretmenlere ayrıca alışılagelmiş bir program ya da müfredatı olmayan, yaş gruplarına ya da kademelere göre sınıf ayrımı yapmayan, öğrenmeyi sadece öğrenenlerin gelişimlerine ve ilgilerine göre düzenleyen demokratik okul olarak adlandırılabilecek alternatif eğitim; herhangi bir okula gitmeden örgün eğitimin sınırları dışında öğrenme ortamı sağlayan okulsuz eğitim ile aileler tarafindan oluşturulan kooperatiflerin kurduğu ve yürüttüğü veli girişimi olan ebeveyn inisiyatifli okullara ilişkin bilgi sahibi olma durumlarına yönelik sorulan soruya, katılımcı öğretmenlerin yarısı bu konuda fikir sahibi olmadığg yönünde görüş bildirmiştir. Öğretmenlerin 15 tanesi bu girişimleri sadece duymuş olduklarını, fakat konu hakkında çok fazla bilgiye sahip olmadıklarını belirtmiştir. Bulgulara göre bu araştırmanın bir sonucu olarak, okul öncesi öğretmenlerinin alternatif eğitim kavramını tanımlayabildikleri, fakat içeriği hakkında (okullar, uygulamalar, örnekler) yeterli bilgiye sahip olamadıkları söylenebilir. Bu durum öğretmenlerin eğitime yönelik uygulamalarında geleneksel eğitim anlayışlarını kullandığı, öğrencilerin öğrenme sürecine aktif katılımını sağlamada mevcut bilgilerinin dışında farklı yaklaşım ve uygulamaları öğrenme ve uygulama konusunda yetkin olmadıkları olarak değerlendirilebilir.

Araştırmanın bir başka bulgusuna göre öğretmenler tarafından okul öncesi eğitimde uygulanan farklı yaklaşımlardan en çok bilinen yaklaşımın Montessori Yaklaşımı $(n=30)$ olduğu görülmüştür. Bunu High Scope Yaklaşımı (n=12), Waldorf Yaklaşımı (n=7), Reggio Emilia Yaklaşımı ( $\mathrm{n}=6)$, Pikler Pedagojisi $(\mathrm{n}=3)$ ve Scamper Yaklaşımı $(\mathrm{n}=2)$ takip etmektedir. Okul öncesi eğitimde farklı yaklaşım ve modeller arasında Montessori Yaklaşımı, Reggio Emilia Yaklaşımı, Proje Yaklaşımı, High Scope Yaklaşımı, Head Start Yaklaşımı, Bank Street Yaklaşımı, Yapılandırmacı Yaklaşım, Waldorf Yaklaşımı, Açık Eğitim, Çocuktan Çocuğa Yaklaşım, Ev okulu gibi uygulamalar yer almaktadır (Başal, 2010; Dündar, 2007; Şahin, 2014; Temel, 2012). Öğretmenler tarafından en çok bilinen bu yaklaşımlar incelendiğinde Türkiye' de yapılan çalışmaların ağırlıklı olarak bu yaklaşımları içerdiği görülmektedir. Montessori Yaklaşımı (Aral, Yıldız Bıçakçı, Yurtyeri Tiryaki, Çetin Sultanoğlu ve Şahin, 2015; Bayer, 2015; Bayram, 2014; Büyüktaşkapu, 2012; Danişman, 2012; Durakoğlu, 2014; Güleş, 2016; Gülkanat, 2015; Kayılı ve Kuşçu, 2012; Kayılı, 2015; Keçecioğlu, 2015; Kuşçu, Bozdaş ve Yıldırım Doğru, 2014; Özdağ, 2014; Selçuk, 2016; Soydan, 2013; Şahin, Sak ve Tuncer, 2013; 
Şahintürk, 2012; Şeker, 2015; Temel, Kaynak, Pasl1, Demir ve Çemrek, 2016; Tepeli ve Y1lmaz, 2012; Toran ve Temel, 2014; Ültanır, 2012; Y1ldırım, Akman ve Alabay, 2012) ile ilgili yapılmış akademik çalışmaların sayıca daha fazla olduğu gözlenmiştir. Bunu Reggio Emilia Yaklaşımı (Büyüktaşkapu Soydan ve Dereli, 2014; Dereli, 2013; Gencer ve Gönen, 2015; Kayır, 2015; Özdemir, 2013; Pekdoğan, 2012; Sak, 2014), Proje Yaklaşımı (Angın, 2013; Çağlar Kabacık, 2016; Erol, 2016; Oğuz, 2012; Özkubat, 2013), High Scope Yaklaşımı (Ezmeci ve Akman, 2016; Gökmen, Deveci, Bingöl, Bekir, Temel ve Kanat, 2016) ve Waldorf Yaklaşımı (Kaya ve Gündüz, 2015; Çelik, 2013) izlemektedir. Genel olarak eğitimde farklı alternatif yaklaşımlardan en fazla bilinen yaklaşımın Montessori Yaklaşımı ve devamında Reggio Emilia, High Scope, Waldorf Yaklaşımı gibi yaklaşımlar olduğu açıkça görülmektedir.

Okul öncesi öğretmenlerinin farklı eğitim yaklaşımlardan hangilerini eğitim planlarına yansıttıkları, ne tür uygulamalar gerçekleştirdikleri incelendiğinde ise, öğretmenlerin 36 tanesi eğitim programlarında farklı yaklaşımları kullanmadığı yönünde görüş bildirmiştir. Bulguya göre araştırmanın bir diğer sonucu ise öğretmenlerin genel olarak okul öncesi eğitimde kullanılan farklı yaklaşımlar konusunda sadece ismen bilgi sahibi oldukları fakat birebir herhangi bir farklı eğitim yaklaşımını günlük eğitim akışlarına ve eğitim programlarına açıkça yansıtmadıkları ve sınıflarında uygulamada sıkıntı yaşadıklarıdır. Aslında ülkemizde uygulanan okul öncesi eğitim programı farklı yaklaşım ve modellerdeki çocuk merkezli uygulamaları temel alarak oluşturulmuş bir eğitim programıdır (MEB, 2013). Tuncer (2015) amaç, plan, uygulama, materyaller, öğretmen ve çocuğun rolleri gibi noktaları dikkate alarak ülkemizde uygulanan okul öncesi eğitim programını Montessori, Reggio Emilia, High Scope ve Head Start Yaklaşımı gibi farklı alternatif eğitim yaklaşımlarıyla karşılaştırmıştır. Yaptığı inceleme sonucunda ise okul öncesi eğitim programının amaçlar ve materyal yönünden farklı yaklaşımlarla benzerlik gösterdiği fakat uygulama, öğretmen ve çocuğun rolü bakımından ise benzerlik göstermediği sonucuna ulaşmıştır. Okul öncesi sınıflarında çocukların pasif kaldığ1 ve öğretmenin daha aktif bir rol oynadığını ve uygulamalarda farklılıklar olduğunu saptamıştır. Memduhoğlu, Mazlum ve Alav (2015) 25 katılımcıyla gerçekleştirdikleri araştırmada eğitimcilerin alternatif eğitim uygulamaları ile ilgili ne düzeyde bilgiye sahip olduklarını incelemişler ve katılımcıların yaklaşık yarısının alternatif eğitim uygulamalarıyla ilgili bilgiye sahip olmadığına ulaşmışlardır. Aynı şekilde Kalıpçı (2008) okul öncesi öğretmenlerinin eğitim uygulamalarında benimsedikleri yaklaşımların belirlenmesi amacıyla gerçekleştirdiği araştırmada, öğretmenlerin Montessori, Waldorf, Reggio Emilia ve John Dewey gibi yaklaşımların niteliklerini uygulamalarında yansıtmadıklarına ulaşmıştır. Önceden yapılmış 
araştırmalar ve bu araştırmanın sonucu çerçevesinde; okul öncesi öğretmenlerinin farklı yaklaşımları uygulamalarına yansıtmamalarının sebepleri arasında, öğretmenlerin farklı eğitim yaklaşımlarını uygulama konusunda örneklerle karşılaşmamış olabilecekleri, uygulama konusundaki bilgi düzeylerinin eksik olabileceği, sınıflarında uygulamaları yapacak çeşitli donanıma (mekân, çocuk sayısı, sosyo ekonomik şartlar vb.) sahip olamayabilecekleri gibi etmenlerin yer alabileceği düşünülmektedir.

Araştırmanın bir başka bulgusuna göre ise katılımcı öğretmenlerin çok büyük bir kısmı (n=40) farklı eğitim yaklaşımlarıyla ilgili makale veya kitap okumadığını belirtmektedir. Aynı şekilde öğretmenlerin yine büyük bir çoğunluğu $(n=31)$ okul öncesi eğitimde farklı eğitim yaklaşımlarıyla ilgili herhangi bir eğitime katılmamıştır. Bu bulgular da okul öncesi öğretmenlerinin niçin eğitimdeki farklı alternatif yaklaşımları günlük eğitim akışlarına yansıtabilecek bilgi düzeyine sahip olmadıklarını da destekler niteliktedir.

Araştırmanın bir başka bulgusuna göre ise okul öncesi öğretmenlerinin farklı eğitim yaklaşımlarıyla ilgili Milli Eğitim Bakanlığı' ndan beklentilerine yönelik verdikleri en çarpıcı sonuç hizmet içi eğitimlerin içeriğinin zenginleştirilmesi ve eğitim veren kişilerin yeterliğinin artırılması yönünde olmuştur. $\mathrm{Bu}$ doğrultuda öğretmenlerin hizmet öncesi ve hizmet içi eğitimlerinde farklı eğitim yaklaşımlarının uygulamalarını içeren eğitimlerin artırılmasının gerekliliği sonucuna varılmaktadır. Bununla beraber öğretmenlerin Milli Eğitim Bakanlığ1 tarafından gerçekleştirilen bu eğitimlere gönüllü olarak katılmaları ve eğitimler sırasında öğrendiklerini de istekli bir şekilde uygulamalarına yansıtmalarının da önemli olduğu unutulmamalıdır. Öğretmenleri bu tür eğitimlere istekli katılımlarının artırılması için, verilen hizmet içi eğitimlerin daha verimli, kapsamlı, bilgilendirici, öğretmenleri motive edici, aktif, planlı ve düzenli bir şekilde farklı ortamlarda ve farklı okullarla birlikte düzenlenmesi ve uygulanması önerilebilir. Ayrıca eğitimi veren kişilerin yeterliliklerinin artırılması ve eğitimlerin uygun şekilde öğretmenlere duyurulması ve öğretmenlerin bilgilendirilmesi de dikkat edilmesi gereken önemli bir husustur. Okul öncesi eğitim sınıflarının ve eğitim ortamlarının farklı yaklaşımları temele alan uygulamaların gerçekleştirilebileceği şekilde düzenlenmesi, sınıf mevcutlarının azaltılması gibi fiziksel müdahaleler de bu konuda yararlı olabilir. Bununla beraber fakültelerdeki okul öncesi eğitim lisans programlarında eğitimde alternatif yaklaşımlara dair zorunlu derslerin yer alması da, öğretmen adaylarının bu konuda daha fazla bilgi sahibi olmaları ve alana çıktıklarında çeşitli uygulamaları gerçekleştirebilecek yeterliğe sahip olabilmeleri açısından önem taşımaktadır. Okul öncesi dönemden başlayarak çocuklara demokratik ortamların sunulması, her çocuğun kendine özgü gelişimini, öğrenme 
hızına ve biçimine göre sürdürebilir şekilde başarı ile sağlanması okul öncesi öğretmenlerinin ve öğretmen adaylarının en temel amacı olmalıdır.

\section{KAYNAKÇA}

Angın, D. E. (2013). Proje temelli eğitim programının 60-71 aylık çocukların kavram gelişimine etkisi. Yayımlanmamış Doktora Tezi. Selçuk Üniversitesi/ Sosyal Bilimler Enstitüsü, Konya.

Aral, N., Yıldız Bıçakçı, M., Yurtyeri Tiryaki, A., Çetin Sultanoğlu, S. \& Şahin, S. (2015). Montessori eğitiminin çocukların gelişimine etkisinin incelenmesi. Hacettepe Üniversitesi Ĕ̆itim Bilimleri Enstitüsü Eğitim Araştırmaları Dergisi, 1(1). 32- 52.

Aslan, F. (2010). Okul öncesi eğitim kurumlarında dış mekân tasarımında çocukların beklentilerinin belirlenmesi. Yayımlanmamış Doktora Tezi). Ankara Üniversitesi/ Fen Bilimleri Enstitüsü, Ankara.

Başal, H. A. (Ed.) (2010). Okul öncesi eğitiminde uygulanan farklı modeller. Bursa: Dora.

Bayer, A. (2015). Montessori yönteminin okul öncesi (36-66 ay) çocuklarının öz bakım becerilerine etkisinin incelenmesi. Yayımlanmamış Yüksek Lisans Tezi. Selçuk Üniversitesi/ Sosyal Bilimler Enstitüsü, Konya.

Bayram, B. (2014). Değerler eğitiminde Montessori yöntemi. Yayımlanmamış Yüksek Lisans Tezi. Üsküdar Üniversitesi/ Sosyal Bilimler Enstitüsü, İstanbul.

Büyüköztürk, Ş., Çakmak, K. E., Akgün, E. Ö., Karadeniz, Ş. \& Demirel, F. (2014). Bilimsel araştırma yöntemleri. Ankara: Pegem Akademi.

Büyüktaşkapu Soydan, S. \& Dereli, H. M. (2014). Farklı yaklaşımları uygulayan okul öncesi öğretmenlerinin çocuklarda düşünme becerilerini geliştirmek için kullandıkları stratejilerin incelenmesi, Kastamonu Eğitim Dergisi, 22(2), 475- 496.

Büyüktaşkapu, S. (2012). Montessori yaklaşımı ve okul öncesinde fen eğitimi. Tübav Bilim Dergisi, 5(3). 19-25.

Carnie, F. (2003). Alternative approaches to education: A guide for parents and teachers. London: RoutledgeFalmer.

Çağlar Kabacık, S. (2016). Anasınıfına devam eden çocukların sebzelere ilişkin tutumlarının incelenmesi: proje etkinlikleri. Yayımlanmamış yüksek lisans tezi. Çukurova Üniversitesi/ Sosyal Bilimler Enstitüsü, Adana.

Çelik, M. (2013). Öğrenme çocuk ile büyür: Erken çocukluk eğitiminde Waldorf yaklaşımı. Erzincan Üniversitesi Eğitim Fakültesi Dergisi,15(2), 39- 51.

Danişman, Ş. (2012). Montessori yaklaşımına genel bir bakış ve eğitim ortamının düzenlenmesi. Eğitimde Politika Analizi Dergisi, 1(2), 85- 113.

Dereli, H. M. (2013). Reggio Emilia temelli dokümantasyon eğitiminin okul öncesi ögretmenlerinin demokratik tutum ve çocuk-merkezli uygulamaları üzerindeki etkisi. Yayımlanmamış Yüksek Lisans Tezi. Hacettepe Üniversitesi/ Eğitim Bilimleri Enstitüsü, Ankara.

Durakoğlu, A. (2014). Environmental education in the context of child's interaction with nature according to Maria Montessori. Anthropologist, 18(2), 309-313 
Dündar, S. (2007). Alternatif eğitimin felsefî temelleri ve alternatif okullardaki uygulamalar. Yayımlanmamış Yüksek Lisans Tezi. Marmara Üniversitesi/ Eğitim Bilimleri Enstitüsü, İstanbul.

Erol, A. (2016). Proje yaklaşımına dayanan aile katılımlı çevre eğitimi programının 5-6 yaş çocuklarının çevreye yönelik farkındalık ve tutumlarına etkisinin incelenmesi. Yayımlanmamış Yüksek Lisans Tezi. Pamukkale Üniversitesi/ Eğitim Bilimleri Enstitüsü, Denizli.

Ezmeci, F. \& Akman, B. (2016). Erken çocukluk döneminde düşünme becerileri Reggio Emilia yaklaşımı ve high/scope programı. Uluslararası Erken Çocukluk Eğitimi Çalışmaları Dergisi, 1(1), 1- 13.

Gencer, A. A. \& Gönen, M. (2015). Examination of the effects of Reggio Emilia based projects on preschool children's creative thinking skills. Procedia-Social and Behavioral Sciences, 186, 456-460.

Gökmen, A. H., Deveci, H., Bingöl, K., Bekir, H., Temel, Z. F. \& Kanat, K. K. (2016). Okul öncesi öğretmenlerinin high/scope yaklaşımı inançları ile özyeterlik inançları arasındaki ilişsinin incelenmesi. Kastamonu Ĕgitim Dergisi, 24(5), 2481- 2500.

Güleş, F. (2016). Raising socially responsible individuals: Montessori education model. The Online Journal of Science and Technology, 6(1), 59- 63.

Gülkanat, P. (2015). Okulöncesi ögrretmenlerinin Montessori yöntemi ile gerçekleştirilen eğitim uygulamalarına ilişkin görüşlerinin incelenmesi. Yayımlanmamış Yüksek Lisans Tezi. Yeditepe Üniversitesi/ Eğitim Bilimleri Enstitüsü, İstanbul.

Kalıpçı, S. (2008). Okul öncesi öğretmenlerinin uygulamalarında benimsedikleri ĕgitimsel yaklaşımları belirleme. Yayımlanmamış Yüksek Lisans Tezi. Marmara Üniversitesi/ Eğitim Bilimleri Enstitüsü, İstanbul.

Kaya, D. \& Gündüz, M. (2015). Alternatif eğitim ve toplumsal değişim üzerindeki etkisi: "Waldorf Okulları Örneği”. Milli Eğitim, 205, 5- 25.

Kayılı, G. (2015). Sosyal beceri ĕgitimi programı ile desteklenmiş Montessori yönteminin anaokulu çocuklarının duyguları anlama ve sosyal problem çözme becerilerine etkisi. Yayımlanmamış Doktora Tezi. Selçuk Üniversitesi/ Sosyal Bilimler Enstitüsü, Konya.

Kayılı, G. \& Kuşçu, Ö. (2012). Examination of social competence and school adjustment of primary school children who had pre-school education with the Montessori method. Journal of Teaching and Education, 1(2), 399- 405.

Kayır, G. (2015). Okul öncesi eğitimde Reggio Emilia yaklaşımı'ndan esinlenerek yapılan proje çalışmaları: bir eylem araştırması. Yayımlanmamış Yüksek Lisans Tezi. Dumlupınar Üniversitesi/ Eğitim Bilimleri Enstitüsü, Kütahya.

Keçecioğlu, Ö. (2015). Meb okul öncesi eğitim programı ve Montessori yaklaşımına göre eğitim alan 5 yaş çocuklarının sosyal becerilerinin incelenmesi. Yayımlanmamış Yüksek Lisans Tezi). Marmara Üniversitesi/ Eğitim Bilimleri Enstitüsü, İstanbul.

Kim, J. \& Suen, H. K. (2003). Predicting children's academic achievement from early assessment scores: a validity generalization study. Early Childhood Research Quarterly, 18(4), 547-566.

Kuşçu, Ö., Bozdaş, Y. \& Yıldırım Doğru, S.S. (2014). Montessori eğitiminin çocuklarda sorumluluk alma, sırasını bekleme, başladığı işi bitirme becerisine etkisinin değerlendirilmesi. Değerler Ĕ̈itimi Dergisi, 12(27). 307- 322. 
Lester, S. (1999). An introduction to phenomenological research. Erişim Tarihi 28 Mayıs 2017, https://www.rgs.org/NR/rdonlyres/F50603E0-41AF-4B15-9C84-

BA7E4DE8CB4F/0/Seaweedphenomenologyresearch.pdf.

Marton, F. (2001). Phenomenography: A research approach to investigating different understandings of reality. Robert R Sherman ve Rodman B Webb (Ed.), Qualitative research in education: Focus and methods içinde (s. 141- 161). London: RoutledgeFalmer.

MEB, (2013). Okul Öncesi Ĕ̆itim Programı. Ankara

Memduhoğlu, H. B., Mazlum, M. M., \& Alav, Ö. (2015). Türkiye'de alternatif eğitim uygulamalarına ilişkin öğretmenlerin ve öğretim üyelerinin görüşleri. Eğitim ve Bilim, 40(179), 69- 87.

Nacaroğlu, G. (2014). Okul öncesi kaynaştırma ĕgitimi uygulamalarının öğretmen tutumlarına göre incelenmesi (Gaziantep ili örneği). Yayımlanmamış Yüksek Lisans Tezi. Gaziantep Üniversitesi/ Eğitim Bilimleri Enstitüsü, Gaziantep.

Oğuz, V. (2012). Proje yaklaşımının anasınıfina devam eden çocukların problem çözme becerilerine etkisinin incelenmesi. Yayımlanmamış Doktora Tezi. Ankara Üniversitesi/ Fen Bilimleri Enstitüsü, Ankara.

Özdağ, A. S. (2014). Montessori metodu 'nun eğitim mekânlarına yansıması üzerine kavramsal bir analiz. Yayımlanmamış Yüksek Lisans Tezi. Karadeniz Teknik Üniversitesi/ Fen Bilimleri Enstitüsü, Trabzon.

Özdemir, C. C. (2013). Okul öncesi öğretmenliği 3. sınıf öğrencilerine verilen Reggio Emilia yaklaşımı konulu ĕgitim programının etkililiğinin incelenmesi. Yayımlanmamış Yüksek Lisans Tezi. Abant İzzet Baysal Üniversitesi/ Eğitim Bilimleri Enstitüsü, Bolu.

Özkubat, S. (2013). Proje yaklaşımı ve okul öncesi dönemdeki yeri. Adnan Menderes Üniversitesi Ĕgitim Fakültesi Ĕgitim Bilimleri Dergisi, 4(1), 36-44.

Pekdoğan, S. (2012). Reggio Emilia yaklaşımı üzerine bir çalışma. Abant İzzet Baysal Üniversitesi Eğitim Fakültesi Dergisi, 237- 246.

Sak, İ. T. Ş. (2014). Okul öncesi öğretmen adaylarının Montessori ve Reggio Emilia yaklaşımları ile ilgili görüşleri. İnönü Üniversitesi Eğitim Fakültesi Dergisi, 15(3), 1 20.

Selçuk, S. K. (2016). Montessori yönteminin anaokulu çocuklarının büyük kas becerilerine etkisinin incelenmesi. Yayımlanmamış Yüksek Lisans Tezi. Necmettin Erbakan Üniversitesi/ Sosyal Bilimler Enstitüsü, Konya.

Senemoğlu, N. (1994). Okul öncesi eğitim programı hangi yeterlikleri kazandırmalıdır? Hacettepe Üniversitesi Eğitim Fakültesi Dergisi, 10, 21-30.

Siraj-Blatchford, I. (2004). Educational disadvantage in the early years: how do we overcome 1t? Some lessons from research. European Early Childhood Education Research Journal, 12(2), 5-20.

Soydan, S. (2013). Çocuklarda merak duygusunu uyandırmada Montessori öğretmenlerinin kullandıkları stratejiler. Mehmet Akif Ersoy Üniversitesi Ĕ̌itim Fakültesi Dergisi, 13(25), 269- 290. 
Soydan, S. (2013). Erken çocukluk yaklaşımlarına ilişkin görüşler ölçeği’ nin Türkçe uyarlaması: Geçerlik ve güvenirlik çalışması. Ahi Evran Üniversitesi Kırşehir Eğitim Fakültesi Dergisi (KEFAD), 14(1), 227- 242.

Şahin, D. (2014). Erken çocukluk dönemine yönelik temel eğitim programları ve yaklaşımlar. İbrahim H. Diken (Ed.), Erken Çocukluk Eğitimi içinde (s. 93- 134). Ankara: Pegem.

Şahin, İ. T., Sak, R.\& Tuncer, N. (2013). Okul öncesi ve birinci sınıf öğretmenlerinin ilköğretime hazırlık sürecine ilişkin görüşlerinin karşılaştırılması. Kuram ve Uygulamada Ĕgitim Bilimleri, 13(3), 1691- 1713.

Şahintürk, Ö. (2012). Montessori yönteminin okul öncesi dönemde öğrencilerin yaratıcı düşünmelerine etkisi. Yayımlanmamış Yüksek Lisans Tezi. Zonguldak Karaelmas Üniversitesi/ Sosyal Bilimler Enstitüsü, Zonguldak.

Şeker, N. K. (2015). Kırsal bölgede okul öncesi eğitime devam eden 5 yaş çocukları ile Montessori eğitimi alan 5 yaş çocukların motor becerilerinin karşılaştırılması. Yayımlanmamış Yüksek Lisans Tezi. Selçuk Üniversitesi/ Sosyal Bilimler Enstitüsü, Konya.

Temel, F. Z. (2005). Okul öncesi eğitimde yeni yaklaşımlar. Bilim ve Aklın Aydınlı̆̆ında Ĕ̆gitim Dergisi, 6, 62.

Temel, F. Z. (Ed.) (2012). Erken çocukluk eğitiminde yaklaşımlar ve programlar. Ankara: Vize Yayıncilik.

Temel, Z. F., Kaynak, B., Paslı, H., Demir, H.\& Çemrek, B. (2016). Montessori eğitim kurumlarındaki çocukların görsel alg1 ve çizim becerileri arasındaki ilişkinin incelenmesi. Kastamonu Ĕgitim Dergisi, 24(5), 2595- 2608.

Tepeli, K.\& Yılmaz, E. (2012). Üç farklı programa göre eğitim alan okul öncesi çocukların sosyal kural algılarının incelenmesi. Selçuk Üniversitesi Sosyal Bilimler Enstitüsü Dergisi, 28, 197- 207.

Tominey, S. \& Rivers, S. E. (2012). Social-emotional skills in preschool education in the state of connecticut: Current practice and implications for child development. William Casper Graustein Memorial Fund. Erişim Tarihi: 1 Şubat 2017. http://ei.yale.edu/wpcontent/uploads/2013/06/Social-Emotional_Skills_CT_Yale.pdf

Toran, M.\& Temel, Z. F. (2014). Montessori yaklaşımın çocukların kavram edinimi üzerindeki etkisinin incelenmesi. Illkögretim Online, 13(1), 223- 234.

Tuncer, B. (2015). Okul öncesi eğitimdeki çağdaş yaklaşımların incelenmesi ve Meb okul öncesi programıyla karşılaştırılması. International Journal of Field Education, 1(2), 3958.

Turaşı1, K. N. (2011). Okul öncesi eğitimin tanımı kapsamı ve önemi. Gelengül Haktanır (Ed.), Okul Öncesi Ĕ̈itime Giriş içinde (s. 1- 23). Ankara: Anı Yayıncılık.

Ültanır, E. (2012). An epistemological glance at the constructivist approach: Constructivist learning in Dewey, Piaget, and Montessori. International Journal of Instruction, 5(2), 195- 212.

Ünal, N. (2006). Okulöncesi ĕgitim kurumlarında görev yapan öğretmenlerin karşılaştıkları sorunlar ve çözüm önerileri. Yayımlanmamış Yüksek Lisans Tezi. Gazi Üniversitesi/ Eğitim Bilimleri Enstitüsü, Ankara. 
Yazar, A. (2007). 1914 - 2006 okul öncesi eğitim programlarında yaratıcılı̆̆ın incelenmesi. Yayımlanmamış Yüksek Lisans Tezi. Atatürk Üniversitesi/ Sosyal Bilimler Enstitüsü, Erzurum.

Yıldırım, A. \& Şimşek, H. (2003). Sosyal bilimlerde nitel araştırma yöntemleri. Ankara: Seçkin Yayınları.

Yıldırım, S., Akman, B.\& Alabay, E. (2012). Okul öncesi dönem çocuklarına sunulan Montessori ve mandala eğitiminin görsel algılama davranışlarına etkisinin incelenmesi. Buca Eğitim Fakültesi Dergisi, 32, 92- 103.

YÖK, (2007). Ĕ̈itim fakültesi ögretmen yetiştirme lisans programları. Ankara

Zvoch, K., Reynolds, R. E. \& Parker, R. P. (2008). Full-day kindergarten and student literacy growth: does a lengthened school day make a difference?. Early Childhood Research Quarterly, 23(1), 94-107. 